\title{
Expression of CCN family members correlates with the clinical features of hepatocellular carcinoma
}

\author{
HEYUN ZHANG ${ }^{1 *}$, WENBIN LI $^{1 *}$, PINBO HUANG $^{1}$, LEHANG LIN $^{2}$, HUA YE $^{1}$, DECHEN LIN $^{3}$, \\ H. PHILLIP KOEFFLER ${ }^{3,4}$, JIE WANG ${ }^{1}$ and DONG YIN ${ }^{2}$
}

\author{
${ }^{1}$ Department of Hepatobiliary Surgery, Sun Yat-Sen Memorial Hospital, Sun Yat-Sen University, Guangzhou 510120; \\ ${ }^{2}$ Guangdong Provincial Key Laboratory of Malignant Tumor Epigenetics and Gene Regulation, Medical Research Center, \\ Sun Yat-Sen Memorial Hospital, Sun Yat-Sen University, Guangzhou 510120, P.R. China; \\ ${ }^{3}$ Division of Hematology/Oncology, Cedars-Sinai Medical Center, UCLA School of Medicine, Los Angeles, CA 90048, USA; \\ ${ }^{4}$ Cancer Science Institute of Singapore, National University of Singapore, Singapore 117599, Republic of Singapore
}

Received September 29, 2014; Accepted December 9, 2014

DOI: 10.3892/or.2015.3709

\begin{abstract}
Studies have reported that the CCN family of proteins plays an important role in stimulating tumorigenesis. However, the relationship between the $\mathrm{CCN}$ protein family members and the features of hepatocellular carcinoma (HCC) remains unclear. The objective of this study was to determine the relationship between the expression levels of $\mathrm{CCN}$ protein family members and the features of HCC. Expression levels of the CCN family of proteins in 80-paired primary HCC samples and 11 normal liver samples were determined by a quantitative real-time PCR assay. Enhanced expression of nephroblastoma overexpressed protein (NOV) and decreased expression of Wnt-induced secreted protein 1 (WISP1), cysteine-rich protein 61 (CYR61) and connective tissue growth factor (CTGF) were found in HCC samples when compared to levels in matched non-cancerous tissues. No significant difference in WISP2 was found between matched-pair samples; only a few samples showed WISP3 expression. Furthermore, the expression levels of NOV, WISP1 and CYR61 were closely correlated with certain clinical features, including venous invasion, cellular differentiation, pTNM stage, disease-free survival and overall survival. Our results suggest that HCC progression may be enhanced by NOV and suppressed by WISP1 and CYR61. Our
\end{abstract}

Correspondence to: Professor Dong Yin, Medical Research Center, Sun Yat-Sen Hospital, Sun Yat-Sen University, 107 Yanjiang West Road, Guangzhou 510120, P.R. China

E-mail: yin_dong@yahoo.com

Professor Jie Wang, Department of Hepatobiliary Surgery, Sun Yat-Sen Memorial Hospital, Sun Yat-Sen University, 107 Yanjiang West Road, Guangzhou 510120, P.R. China

E-mail:sumjw@163.com

*Contributed equally

Key words: CCN family, hepatocellular carcinoma, expression levels, clinical features statistical analysis suggests that these proteins may be valuable in determining the prognosis of this deadly disease and directs attention to modulating the levels of these proteins as a potential mode of therapy.

\section{Introduction}

Primary hepatocellular carcinoma (HCC) is the fifth most common malignancy and the third most frequent cause of worldwide cancer mortality $(1,2)$. Hepatocarcinogenesis consists of multiple steps leading to the accumulation of genetic and epigenetic changes in hepatic cells, which eventually cause malignant progression (3). Recent studies revealed that the $\mathrm{Wnt} / \beta$-catenin and p53 pathways are the two most important pathways in the malignant development of HCC (4).

The CCN family of proteins was named for its first three described members: cysteine-rich protein 61 (CYR61/CCN1), connective tissue growth factor (CTGF/CCN2) and nephroblastoma overexpressed protein (NOV/CCN3) (5). It includes six members: CYR61, CTGF, NOV, Wnt-induced secreted protein 1 (WISP1/CCN4), WISP2/CCN5 and WISP3/CCN6 (6-9). All of the CCN proteins consist of 4 specific structural domains: insulin-like growth factor binding protein, thrombospondin type 1 , Von Willebrand type $\mathrm{C}$ and a $\mathrm{COOH}$-terminal domain. These specific domains display a high homology to the conserved regions of many types of extracellular matrix proteins $(5,10)$.

Previous studies have demonstrated that the $\mathrm{CCN}$ proteins play an important role in stimulating tumorigenesis in many cancers (10-12). Babic et al suggested that CYR61 may activate integrins and induce cell progression in endothelial cells (13). CTGF may stimulate the production of collagen and fibronectin due to its involvement in the TGF- $\beta$ pathway and SMAD signaling $(14,15)$. WISP1 is upregulated in breast cancers of Wnt-1 transgenic mice (8). Additionally, the upregulation of WISP1 may induce the transformation of kidney fibroblasts in normal rats (9). Accumulating evidence has shown that the CCN family proteins participate in many fundamental cellular processes and that their expression is altered during cancer 
development (6,7). Few studies have explored the level of NOV involvement in oncogenesis.

However, correlations between CCN gene expression and clinical features of $\mathrm{HCC}$ remain unexplored. In the present study, we used real-time qPCR to quantify the mRNA levels of the CCN family of genes in HCC samples. Expression levels of these genes were measured in 80 primary HCC samples and matched non-cancerous tissues, as well as in 11 human normal liver samples. We then examined the correlations of $\mathrm{CCN}$ protein expression with clinical and pathological characteristics, as well as survival data in HCC patients using several statistical methods.

\section{Materials and methods}

Patients and samples. Eighty primary HCC tissue samples with matched non-cancerous tissues and 11 normal liver tissue samples were obtained from the tissue bank of Sun Yat-Sen Memorial Hospital, Sun Yat-Sen University (GuangZhou, China) after obtaining informed consent for utilizing the tissue specimens derived from patients. Tissues were obtained during surgical procedures. The matched non-cancerous tissues (NC) were resected at a minimum distance of $2 \mathrm{~cm}$ away from the cancerous tissues. The pathology of each sample was confirmed by histological examination, and the samples were stored at $-80^{\circ} \mathrm{C}$ until RNA was extracted. The use of clinical specimens in the present study was approved by the Ethics Committee of Sun Yat-Sen Memorial Hospital of Sun Yat-sen University. Two of the 80 patients died during the preoperative period, 1 patient was lost during the follow-up period and all other patients participated in regular postoperative follow-up evaluations.

Cellular differentiations of HCC samples were characterized by Edmondson's classification and divided into stages I/II and III/IV. The pTNM stages of patients were divided into two groups: stages I/II and III/IV, as described in the International Union Against Cancer (UICC), 6th edition, 2002.

RNA extraction and cDNA synthesis. Total RNA was extracted from all tested samples using the TRIzol reagent (\#15596-026; Invitrogen Life Technologies, Carlsbad, CA, USA) according to the manufacturer's instructions. The quality of the RNA was determined by electrophoresis on an agarose gel stained with GoldView (Tiangen Biotech Co., Ltd., Beijing, China). A total of $2.5 \mu \mathrm{g}$ of each RNA in a total volume of $50 \mu \mathrm{l}$ was used to generate cDNA by reverse transcription with the PrimeScript ${ }^{\mathrm{TM}}$ RT-PCR kit (\#RR014B Ax4; Takara Biotechnology, Dalian, China), following the manufacturer's instructions.

Real-time quantitative PCR. Real-time qPCR was used to determine the initial detection of the PCR product during the amplification cycle. The parameter $C_{t}$ was defined as the detected cycle number at which the fluorescence reached a fixed threshold value above the baseline. The amount of $\mathrm{CCN}$ mRNA in test samples was quantified by measuring $C_{t}$ and calculating the mRNA concentration from the matched standard curve. Additionally, the amount of $\beta$-actin mRNA was quantified as an endogenous control. Once mRNA concentrations were determined, the quantity of the target gene was
Table I. Oligonucleotide primer sequences used for qPCR.

\begin{tabular}{|c|c|}
\hline Gene & Oligonucleotide sequences \\
\hline
\end{tabular}

\section{CYR61}

5'-primer 5'-TCACCCTTCTCCACTTGACC-3'

3'-primer 5'-AGTCCTCGTTGAGCTGCTTG-3'

CTGF

5'-primer 5'-CAAGGGCCTCTTCTGTGACT-3'

3'-primer 5'-CAGCTGCTCTGGAAGGACTCT-3'

NOV

5'-primer 5'-AAGAGCTGTGGTATGGGGTTC-3'

3'-primer 5'-GGTGGATGGCTTTGAGTGAC-3'

WISP1

5'-primer 5'-CCATACACTCATTAAGGCAGGGAA-3' 105

3'-primer 5'-GGTTGATAGGAGCGTGTGCTG-3'

WISP2

5'-primer 5'-AGCCCAAGGACCCCAGTT-3'

3'-primer 5'-TCTCCAGTCGGCAGAAGC-3'

WISP3

5'-primer 5'-CTGGCCTGGCACAGTTCT-3'

3'-primer 5'-TCTCTCACCAGGCTCACTCC-3'

$\beta$-actin

5'-primer 5'-CTCCCTGGAGAAGAGCTACG-3'

3'-primer 5'-ACAGGACTCCATGCCCAG-3'

CYR61, cysteine-rich 61; CTGF, connective tissue growth factor; NOV, nephroblastoma overexpressed protein; WISP, Wnt-induced secreted protein.

divided by the endogenous reference to obtain a normalized value. Finally, the relative expression levels (termed $\triangle \mathrm{CCN}$ ) of the target genes in the $\mathrm{HCC}$ samples were calculated according to the following formula:

$\Delta \mathrm{CCN}=\left(\mathrm{CCN}_{\mathrm{HCC}} / \beta-\operatorname{actin}_{\mathrm{HCC}}\right) /\left(\mathrm{CCN}_{\text {matched NC}} / \beta-\operatorname{actin}_{\text {matched NC }}\right)$

Primers. Primers (Table I) were designed by performing BLAST searches within the GenBank database to confirm the specificity of the nucleotide sequences and the absence of DNA polymorphisms. At least one of the two primers corresponded to a different exon or the junction between 2 exons to avoid amplification of genomic DNA contamination.

Standard curve construction. The standard templates were constructed according to the manufacturer's instructions described in the qPCR Technical Guideline (16). The standard curve was produced by 10 -fold serial dilution of standard templates. The linear relationship between the $C_{t}$ value and the $\log$ of the initial copy number was clearly demonstrated in all cases. The standard curves for CYR61 were constructed and displayed in Fig. 1.

PCR amplification. The PCR reaction mixture for DNA amplification included $3 \mu \mathrm{l}$ of cDNA, $10 \mu \mathrm{l}$ of GoTaq $^{\circledR}$ qPCR Master Mix (Promega Biotech Co., Ltd., Madison, WI, USA), 

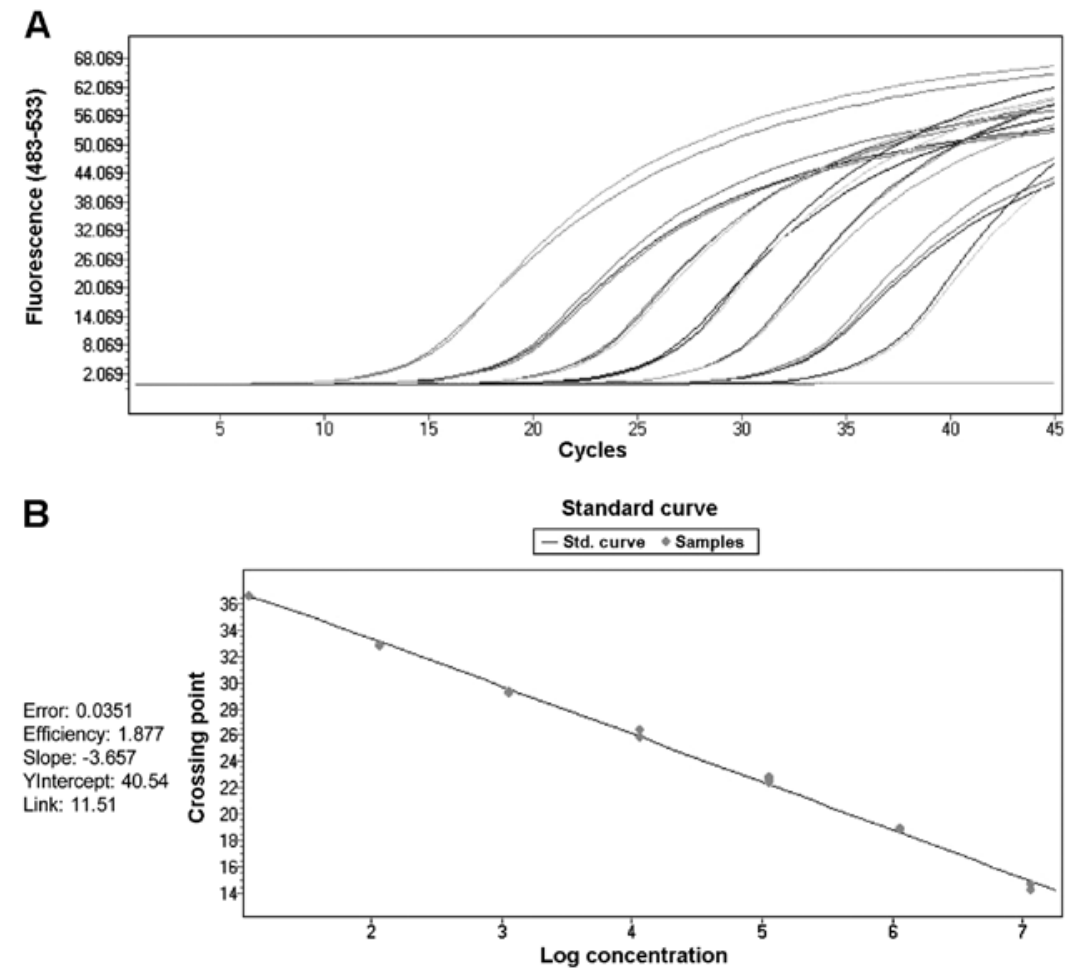

Figure 1. The standard curve of CYR-61. (A) Amplification plots for reactions with 7 points of the CYR-61 standard curve; (B) Standard curve generated after determination of $\mathrm{C}_{\mathrm{t}}$ values plotted against the starting quantity of target DNA. CYR61, cysteine-rich 61

$1 \mu 1$ of each specific primer $(10 \mathrm{nmol} / \mu 1)$, and $5 \mu 1$ of nuclease-free water. All reactions were performed in triplicate in a LightCycler ${ }^{\circledR} 480$ System (F. Hoffmann-La Roche Ltd., Basel, Switzerland). The cycling conditions for the reaction were: $5 \mathrm{~min}$ at $95^{\circ} \mathrm{C}$, followed by 45 cycles at $95^{\circ} \mathrm{C}$ for $10 \mathrm{sec}$, $20 \mathrm{sec}$ at the $\mathrm{Tm}$ of each gene and $72^{\circ} \mathrm{C}$ for $30 \mathrm{sec}$.

Statistical analysis. Student's t-test, the $\chi^{2}$ test, the continuity correction test, Fisher's exact test, the log-rank test and the Cox proportional hazard model were used in this study to explore the relationship between the expression level of each gene and the clinical details, including age, gender, tumor size, $\alpha$-fetoprotein (AFP), HBsAg status, direct liver invasion, bile duct invasion, venous invasion, tumor microsatellite, cellular differentiation, pTNM stage, relapse and survival data. For each gene, Kaplan-Meier analysis of disease-free and overall survival curves for patients were constructed and a log-rank test was used to analyze the equality of the curves. Kappa statistical analysis was used to study the correlations between all pairs of $\mathrm{CCN}$ genes. Cox regression for multivariate survival analysis was used for evaluating the prognosis covariate.

\section{Results}

We used qPCR to examine the relative expression of $\mathrm{CCN}$ family members. A relative expression level of $\triangle \mathrm{CCN}>1$ was set as the criterion for enhanced expression of the $\mathrm{CCN}$ genes in HCC, which resulted in the sample being classified into a positive group, while an expression level of $\triangle \mathrm{CCN} \leq 1$ was considered a decrease in expression and the sample was classified into a negative group.
Expression of NOV in HCC. Normalized mean expression levels (CCN/ $\beta$-actin) of NOV relative to standard curves are shown in Fig. 2A. Statistical analysis showed that NOV was upregulated in primary $\mathrm{HCC}$ samples compared to that in the paired non-cancerous tissues $(\mathrm{P}=0.037)$. Enhanced expression of NOV $(\Delta \mathrm{NOV}>1)$ was found in 44 of $80(55 \%)$ HCC samples compared to the matched non-cancerous tissues (Fig. 3A).

Univariate analysis showed a significant association between the enhanced expression of NOV and several clinical features (venous invasion, cellular differentiation, pTNM stage, disease-free and overall survival) in HCC samples. No significant difference was noted between age, gender, tumor size, AFP, HBsAg status, direct liver invasion, bile duct invasion, tumor microsatellite instability and the expression level of NOV in the HCC samples (Figs. 4A and 5A; Table IIA and Table III).

Expression of WISP1 in HCC. Normalized mean expression levels of WISP1 relative to standard curves are shown in Fig. 2B. Statistical analysis showed that the expression of WISP1 was downregulated in primary HCC samples compared to the levels in the paired non-cancerous $(\mathrm{P}<0.001)$ and normal liver tissues $(\mathrm{P}<0.001)$. Decreased expression of WISP1 ( $\triangle \mathrm{WISP} 1 \leq 1)$ compared to matched non-cancerous tissues was found in 65 of 80 (81\%) HCC samples (Fig. 3B).

Univariate analysis showed significant associations between the decreased expression of WISP1 and several clinical features (tumor size, direct liver invasion, venous invasion, tumor microsatellite instability, pTNM stage, disease-free and overall survival) in HCC samples. No significant differences were noted between the age, gender, AFP, HBsAg status, bile duct 

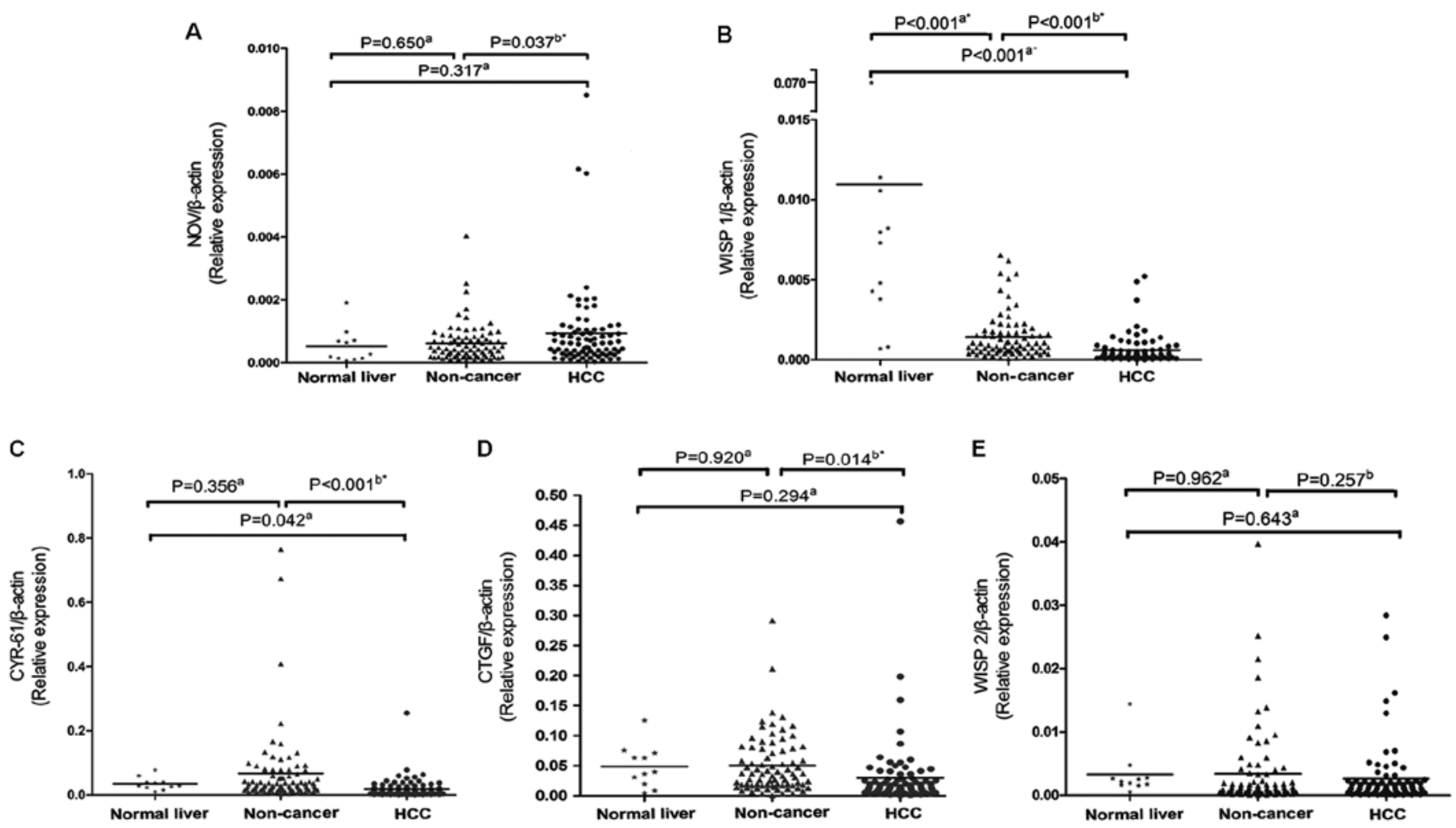

Figure 2. Normalized expression of NOV (A), WISP1 (B), CYR61 (C), CTGF (D), and WISP2 (E) in HCC patients. Normalized expression levels are displayed as a ratio of the expression of $\mathrm{CCN}$ genes in all samples divided by $\beta$-actin. ${ }^{\mathrm{a}}$ Independent-sample t-test. ${ }^{b}$ Paired-sample $\mathrm{t}$-test. HCC, hepatocellular carcinoma; CYR61, cysteine-rich 61; CTGF, connective tissue growth factor; NOV, nephroblastoma overexpressed protein; WISP, Wnt-induced protein.

invasion and cellular differentiation and the expression level of WISP2 in the HCC samples (Figs. 4B and 5B; Table IIA and Table III).

Expression of CYR61 in HCC. Normalized mean expression levels of CYR61 relative to standard curves are shown in Fig. 2C). Statistical analysis showed that CYR61 was downregulated in the primary $\mathrm{HCC}$ samples compared with that in the paired non-cancerous tissues $(\mathrm{P}<0.001)$. Decreased expression of CYR61 $(\triangle \mathrm{CYR61} \leq 1)$ compared to matched non-cancerous tissues was found in 71 of $80(88 \%) \mathrm{HCC}$ samples (Fig. 3C).

Nineteen patients with either enhanced expression of CYR61 $(\triangle C$ CY61 $>1, n=9)$ or expression of CYR61 that was decreased $<2$-fold $(\Delta C Y R>-1, n=10)$ were defined as the CYR61 highexpression group. Samples from these patients were compared to the samples from patients whose CYR61 level was decreased $>2$-fold $(\triangle \mathrm{CYR}<-1, \mathrm{n}=61)$, which were defined as the CYR61 low-expression group. The results of univariate analysis showed a significantly disease-free and longer overall survival in the CYR61 high-expression group. However, no significant differences were noted between the level of CYR61 expression and other clinical features (age, gender, tumor size, AFP, HBsAg status, direct liver invasion, bile duct invasion, venous invasion, tumor microsatellite, cellular differentiation and pTNM stage) (Figs. 4C and 5C; Table IIB and Table III).

Expression of CTGF in HCC. Normalized mean expression levels of CTGF relative to standard curves are shown in Fig. 2D. Statistical analysis showed that CTGF was downregu- lated in the primary HCC samples compared with that in the paired non-cancerous tissues $(\mathrm{P}=0.014)$. Enhanced expression of CTGF ( $\triangle \mathrm{CTGF}>1)$ compared to matched non-cancerous tissues was found in 20 of 80 (25\%) HCC samples (Fig. 3D). Univariate analysis showed that no statistically significant correlations existed between the level of CTGF and any of the clinical features (Figs. 4D and 5D; Table IIB and Table III).

Expression of WISP2 in HCC. Normalized mean expression levels of WISP2 relative to standard curves are shown in Fig. 2E. Statistical analysis showed that the expression levels of WISP2 in primary HCC samples showed no difference from the paired non-cancerous tissues $(\mathrm{P}=0.257)$. Enhanced expression of WISP2 $(\triangle \mathrm{WISP} 2>1)$ compared to matched non-cancerous tissues was found in 38 of $80(47.5 \%)$ HCC samples (Fig. 3E). Univariate analysis demonstrated no statistical correlations between the level of WISP2 expression and any of the clinical features (Figs. 4E and 5E; Table IIB and Table III).

Expression of WISP3 in HCC. Among all of the samples examined, including HCC, NC and normal liver (NL) tissues, only a few $(12 / 171,7 \%)$ expressed WISP3. Therefore, we concluded that WISP3 was not expressed in the liver tissues.

Correlation among the expression levels of the CCN family of genes in HCC samples. The kappa statistical analysis, which defines a significant correlation at a $\kappa$-value $>0.5$, and implies no significant association at a $\kappa$-value $\leq 0.5$, was used to examine the correlation among the expression levels of the 


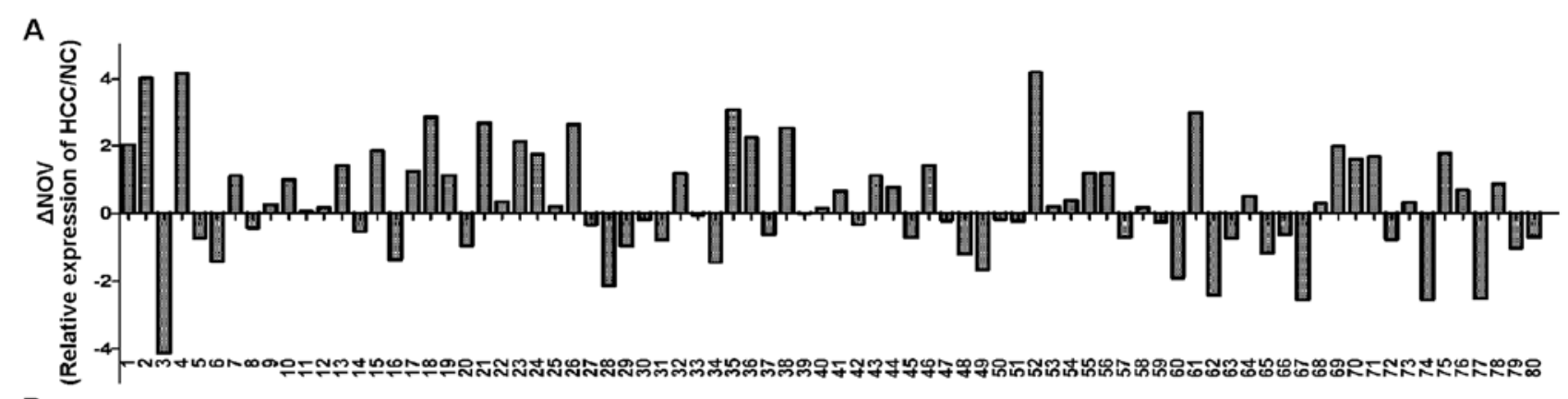

B

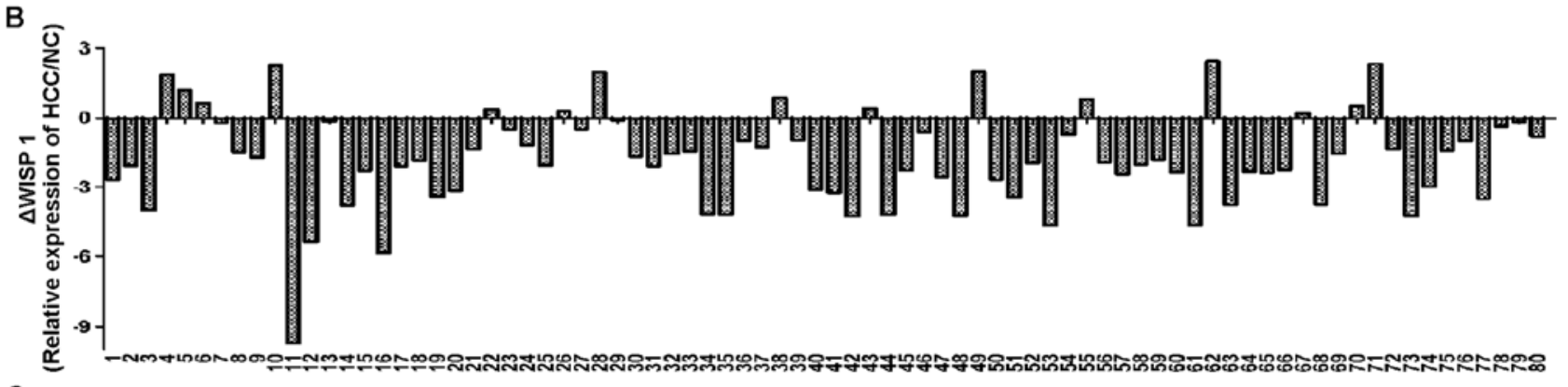

C

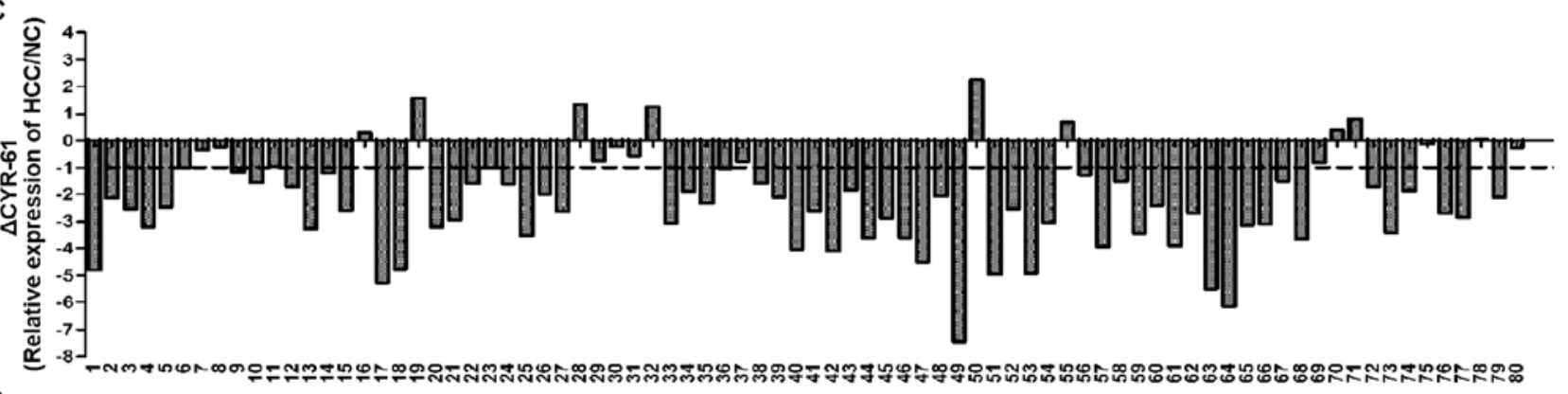

D

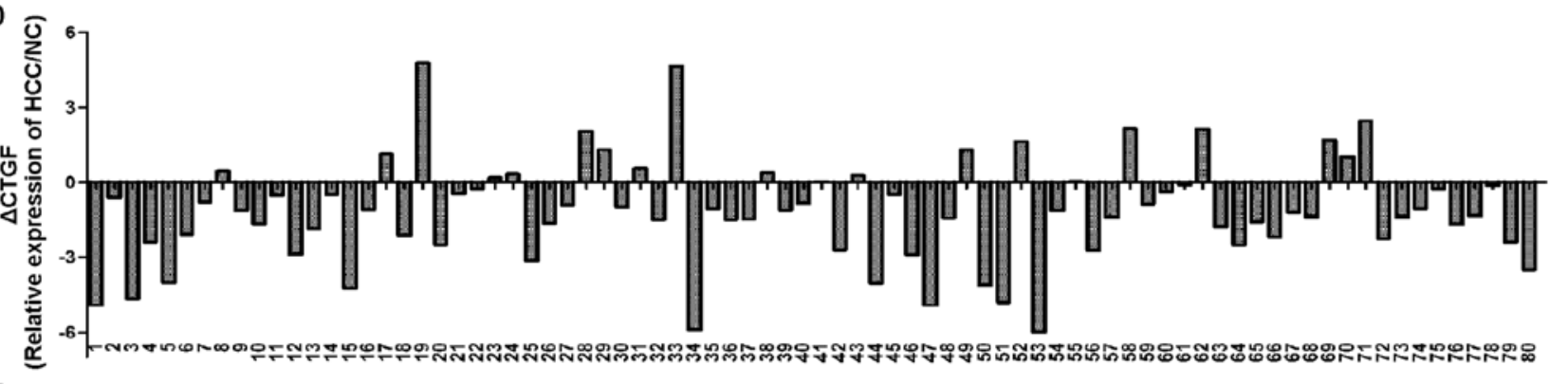

E

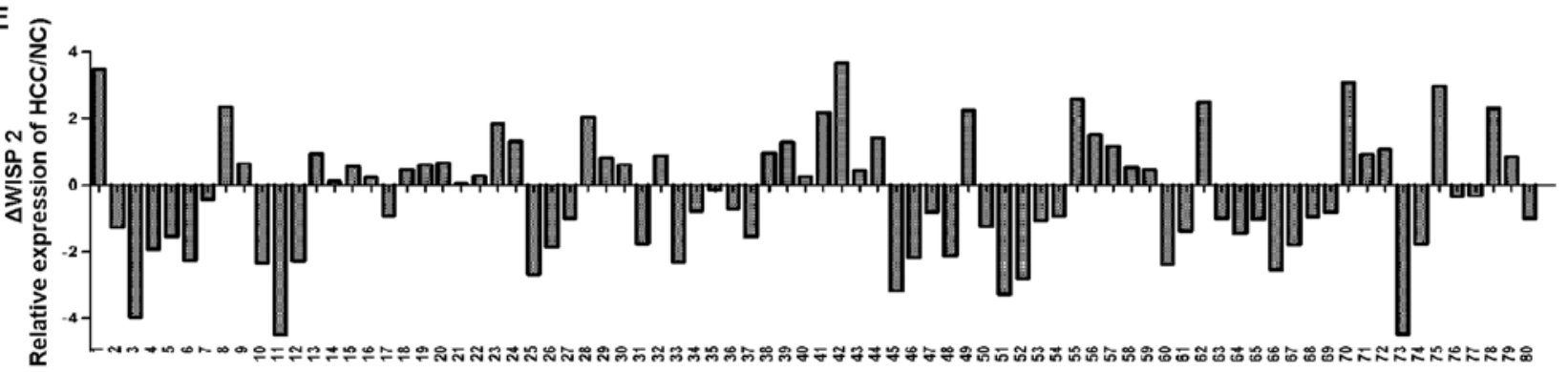

Figure 3. Relative expression of the CCN family in HCC samples compared to matched non-cancer (NC) tissues: NOV (A), WISP1 (B), CYR61 (C), CTGF (D), and WISP2 (E). HCC, hepatocellular carcinoma; CYR61, cysteine-rich 61; CTGF, connective tissue growth factor; NOV, nephroblastoma overexpressed protein; WISP, Wnt-induced protein.

NOV, WISP1, CYR61, CTGF and WISP2 genes. The results showed that no correlation existed among the expression levels of these $5 \mathrm{CCN}$ genes in the HCC patients (Table IV).

Correlation between overall survival and expression of the CCN gene family in HCC samples. Univariate survival analysis with a log-rank test and the Cox proportional hazard model for continuous variables was used to study the relationship between overall survival and the expression of each $\mathrm{CCN}$ gene in the HCC samples (Table III). The overall length of survival was significantly correlated with the expression levels of NOV, WISP1 and CYR61, but not CTGF or WISP2. 

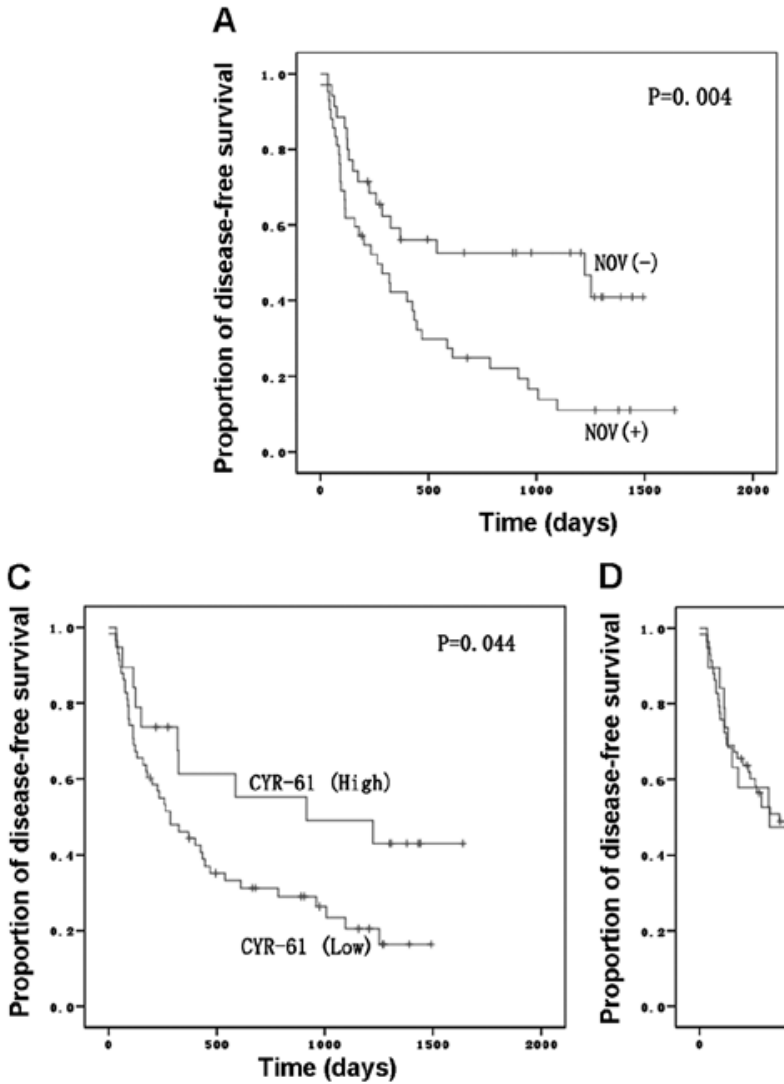

D
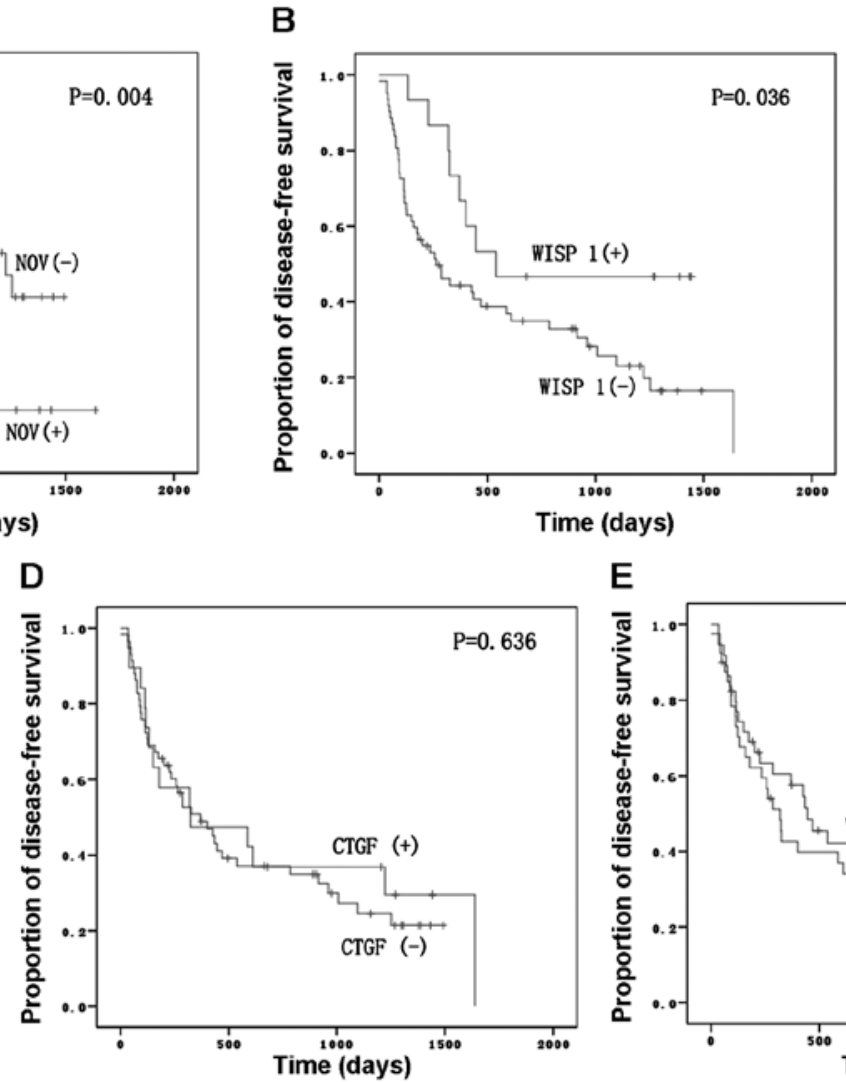

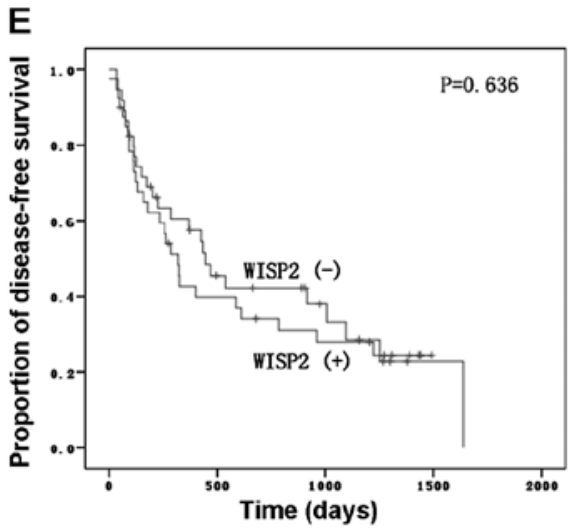

Figure 4. Disease-free survival curves of HCC patients subgrouped according to expression levels of the CCN family: NOV (A), WISP1 (B), CYR61 (C), CTGF (D) and WISP2 (E). HCC, hepatocellular carcinoma; CYR61, cysteine-rich 61; CTGF, connective tissue growth factor; NOV, nephroblastoma overexpressed protein; WISP, Wnt-induced protein.
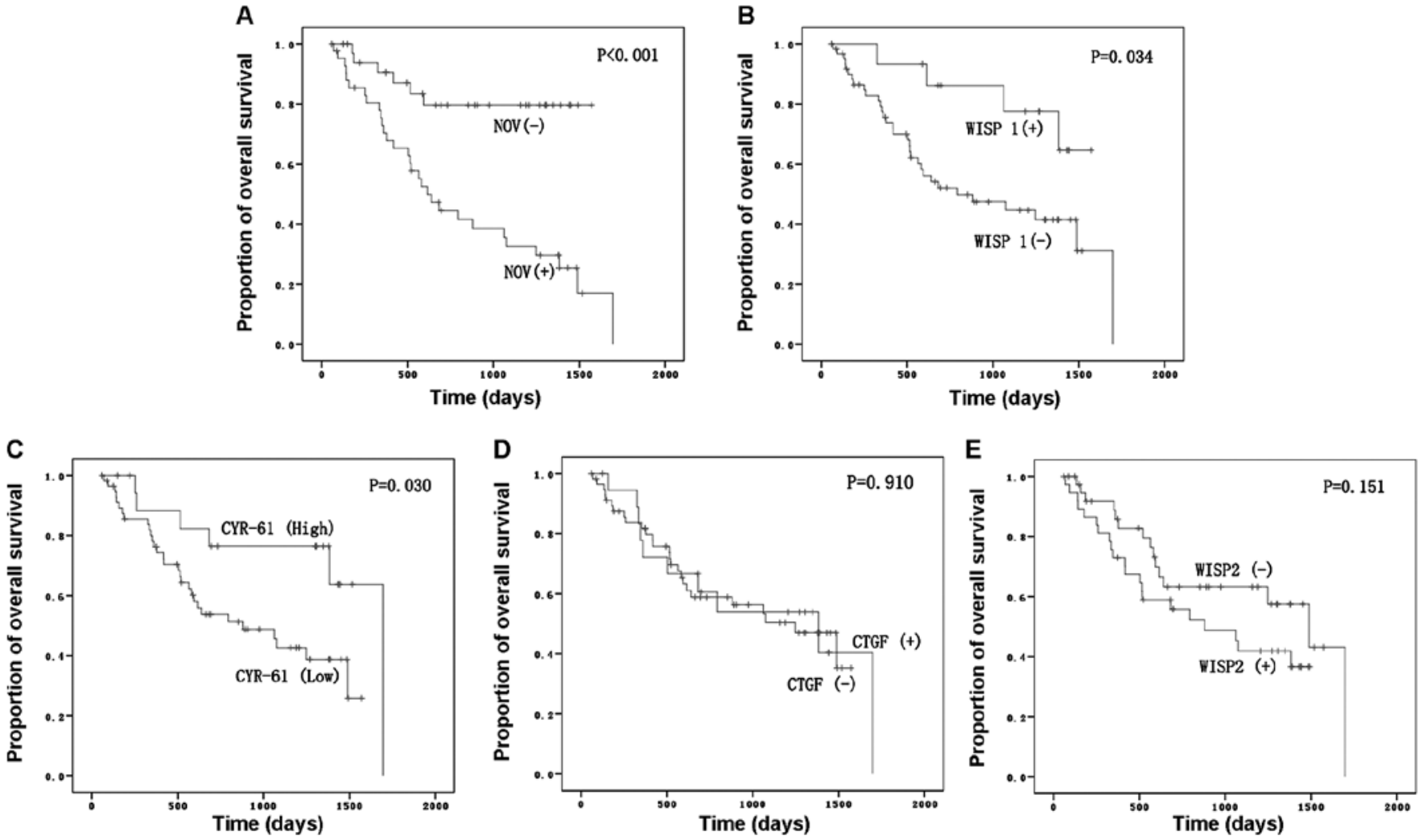

Figure 5. Overall survival curves of HCC patients subgrouped according to expression levels of the CCN family: NOV (A), WISP1 (B), CYR61 (C), CTGF (D) and WISP2 (E). HCC, hepatocellular carcinoma; CYR61, cysteine-rich 61; CTGF, connective tissue growth factor; NOV, nephroblastoma overexpressed protein; WISP, Wnt-induced protein. 
Table II. Relationships between the expression levels of NOV, WISP1, CRY61, CTGF and WISP2 and the clinical features of the HCC patients.

A, Relationships between the expression levels of NOV and WISP1 and the patient clinical features

\begin{tabular}{|c|c|c|c|c|c|c|}
\hline \multirow[b]{2}{*}{ Clinical characteristics } & \multicolumn{2}{|c|}{ NOV expression } & \multirow[b]{2}{*}{ P-value } & \multicolumn{2}{|c|}{ WISP1 expression } & \multirow[b]{2}{*}{ P-value } \\
\hline & $\begin{array}{c}\text { Negative } \\
(n=36)\end{array}$ & $\begin{array}{c}\text { Positive } \\
(n=44)\end{array}$ & & $\begin{array}{c}\text { Negative } \\
(n=65)\end{array}$ & $\begin{array}{c}\text { Positive } \\
(n=15)\end{array}$ & \\
\hline Age (years) & $48.2 \pm 11.1$ & $51.4 \pm 10.5$ & $0.187^{\mathrm{a}}$ & $51.3 \pm 11.7$ & $46.3 \pm 7.5$ & $0.120^{\mathrm{a}}$ \\
\hline Gender & & & $0.234^{\mathrm{b}}$ & & & $0.229^{c}$ \\
\hline Male & 31 & 42 & & 61 & 12 & \\
\hline Female & 5 & 2 & & 4 & 3 & \\
\hline Tumor size $(\mathrm{cm})$ & $7.2 \pm 4.7$ & $8.8 \pm 3.5$ & $0.092^{\mathrm{a}}$ & $8.8 \pm 4.0$ & $5.0 \pm 3.1$ & $0.001^{\mathrm{a}, \mathrm{e}}$ \\
\hline AFP & & & $0.246^{\mathrm{d}}$ & & & $0.336^{\mathrm{d}}$ \\
\hline Negative & 16 & 14 & & 26 & 4 & \\
\hline Positive & 20 & 30 & & 39 & 11 & \\
\hline $\mathrm{HBsAg}$ & & & $0.927^{\mathrm{d}}$ & & & $0.467^{\mathrm{c}}$ \\
\hline Negative & 6 & 7 & & 12 & 1 & \\
\hline Positive & 30 & 37 & & 53 & 14 & \\
\hline Direct liver invasion & & & $0.486^{\mathrm{d}}$ & & & $0.010^{\mathrm{d}, \mathrm{e}}$ \\
\hline Negative & 15 & 15 & & 20 & 10 & \\
\hline Positive & 21 & 29 & & 45 & 5 & \\
\hline Bile duct invasion & & & & & & $0.090^{\mathrm{c}}$ \\
\hline Negative & 32 & 33 & $0.113^{\mathrm{d}}$ & 50 & 15 & \\
\hline Positive & 4 & 11 & & 15 & 0 & \\
\hline Venous invasion & & & $0.021^{\mathrm{d}, \mathrm{e}}$ & & & $0.018^{\mathrm{c}, \mathrm{e}}$ \\
\hline Negative & 16 & 9 & & 16 & 9 & \\
\hline Positive & 20 & 35 & & 49 & 6 & \\
\hline Tumor microsatellite instability & & & $0.271^{\mathrm{d}}$ & & & $0.019^{\mathrm{d}, \mathrm{e}}$ \\
\hline Negative & 24 & 24 & & 35 & 13 & \\
\hline Positive & 12 & 20 & & 30 & 2 & \\
\hline Cellular differentiation & & & $0.036^{\mathrm{d}, \mathrm{e}}$ & & & $0.091^{\mathrm{d}}$ \\
\hline $\mathrm{I} / \mathrm{II}$ & 24 & 19 & & 32 & 11 & \\
\hline III/IV & 12 & 25 & & 33 & 4 & \\
\hline pTNM stage & & & $<0.001^{\mathrm{d}, \mathrm{e}}$ & & & $<0.001^{\mathrm{d}, \mathrm{e}}$ \\
\hline $\mathrm{I} / \mathrm{II}$ & 24 & 12 & & 23 & 13 & \\
\hline III/IV & 12 & 32 & & 42 & 2 & \\
\hline
\end{tabular}

B, Relationships between expression level of CRY61, CTGF, WISP2 and the patient clinical features

\begin{tabular}{|c|c|c|c|c|c|c|c|c|c|}
\hline \multirow[b]{2}{*}{ Clinical characteristics } & \multicolumn{2}{|c|}{ CYR61 expression } & \multirow[b]{2}{*}{ P-value } & \multicolumn{2}{|c|}{ CTGF expression } & \multirow[b]{2}{*}{ P-value } & \multicolumn{2}{|c|}{ WISP2 expression } & \multirow[b]{2}{*}{ P-value } \\
\hline & $\begin{array}{c}\text { Low } \\
(n=61)\end{array}$ & $\begin{array}{l}\text { High } \\
(n=19)\end{array}$ & & $\begin{array}{l}\text { Negative } \\
(n=60)\end{array}$ & $\begin{array}{l}\text { Positive } \\
(n=20)\end{array}$ & & $\begin{array}{l}\text { Negative } \\
(n=42)\end{array}$ & $\begin{array}{c}\text { Positive } \\
(n=38)\end{array}$ & \\
\hline Age (years) & $51.0 \pm 11.0$ & $46.8 \pm 9.8$ & $0.144^{\mathrm{a}}$ & $49.5 \pm 12.1$ & $49.5 \pm 10.4$ & $0.542^{\mathrm{a}}$ & $49.8 \pm 12.2$ & $50.2 \pm 9.2$ & $0.879^{\mathrm{a}}$ \\
\hline Gender & & & $1.000^{\mathrm{b}}$ & & & $0.493^{\mathrm{c}}$ & & & $1.000^{\mathrm{b}}$ \\
\hline Male & 17 & 56 & & 56 & 17 & & 38 & 35 & \\
\hline Female & 2 & 5 & & 4 & 3 & & 4 & 3 & \\
\hline Tumor size $(\mathrm{cm})$ & $8.3 \pm 4.1$ & $7.3 \pm 4.2$ & $0.351^{\mathrm{a}}$ & $8.5 \pm 4.4$ & $6.9 \pm 3.2$ & $0.141^{\mathrm{a}}$ & $8.7 \pm 4.5$ & $7.4 \pm 3.6$ & $0.170^{\mathrm{a}}$ \\
\hline AFP & & & $0.542^{\mathrm{d}}$ & & & $0.424^{\mathrm{d}}$ & & & $0.298^{\mathrm{d}}$ \\
\hline Negative & 24 & 6 & & 21 & 9 & & 18 & 12 & \\
\hline Positive & 37 & 13 & & 39 & 11 & & 24 & 26 & \\
\hline
\end{tabular}


Table II. Continued.

\begin{tabular}{|c|c|c|c|c|c|c|c|c|c|}
\hline \multirow[b]{2}{*}{ Clinical characteristics } & \multicolumn{2}{|c|}{ CYR61 expression } & \multirow[b]{2}{*}{ P-value } & \multicolumn{2}{|c|}{ CTGF expression } & \multirow[b]{2}{*}{ P-value } & \multicolumn{2}{|c|}{ WISP2 expression } & \multirow[b]{2}{*}{ P-value } \\
\hline & $\begin{array}{c}\text { Low } \\
(n=61)\end{array}$ & $\begin{array}{l}\text { High } \\
(n=19)\end{array}$ & & $\begin{array}{l}\text { Negative } \\
(n=60)\end{array}$ & $\begin{array}{l}\text { Positive } \\
(n=20)\end{array}$ & & $\begin{array}{c}\text { Negative } \\
(n=42)\end{array}$ & $\begin{array}{c}\text { Positive } \\
(n=38)\end{array}$ & \\
\hline HBsAg & & & $0.769^{\mathrm{b}}$ & & & $0.115^{\mathrm{c}}$ & & & $0.617^{\mathrm{d}}$ \\
\hline Negative & 9 & 4 & & 7 & 6 & & 6 & 7 & \\
\hline Positive & 52 & 15 & & 53 & 14 & & 36 & 31 & \\
\hline Direct liver invasion & & & $0.946^{\mathrm{d}}$ & & & $0.424^{\mathrm{d}}$ & & & $0.563^{\mathrm{d}}$ \\
\hline Negative & 23 & 7 & & 21 & 9 & & 17 & 13 & \\
\hline Positive & 38 & 12 & & 39 & 11 & & 25 & 25 & \\
\hline Bile duct invasion & & & $0.101^{\mathrm{d}}$ & & & $0.408^{\mathrm{c}}$ & & & $0.943^{\mathrm{d}}$ \\
\hline Negative & 9 & 6 & & 47 & 18 & & 34 & 31 & \\
\hline Positive & 52 & 13 & & 13 & 2 & & 8 & 7 & \\
\hline Venous invasion & & & $0.547^{\mathrm{d}}$ & & & $0.889^{\mathrm{c}}$ & & & $0.587^{\mathrm{d}}$ \\
\hline Negative & 18 & 7 & & 19 & 6 & & 12 & 13 & \\
\hline Positive & 43 & 12 & & 41 & 14 & & 30 & 25 & \\
\hline $\begin{array}{l}\text { Tumor microsatellite } \\
\text { instability }\end{array}$ & & & $0.391^{\mathrm{d}}$ & & & $0.292^{\mathrm{d}}$ & & $0.927^{\mathrm{d}}$ & \\
\hline Negative & 26 & 6 & & 34 & 14 & & 25 & 23 & \\
\hline Positive & 35 & 13 & & 26 & 6 & & 17 & 15 & \\
\hline Cellular differentiation & & & $0.678^{\mathrm{d}}$ & & & $0.518^{\mathrm{d}}$ & & & $0.108^{\mathrm{d}}$ \\
\hline $\mathrm{I} / \mathrm{II}$ & 32 & 11 & & 28 & 11 & & 19 & 24 & \\
\hline III/IV & 29 & 8 & & 32 & 9 & & 23 & 14 & \\
\hline pTNM stage & & & $0.444^{\mathrm{d}}$ & & & $0.604^{\mathrm{d}}$ & & & $0.685^{\mathrm{d}}$ \\
\hline $\mathrm{I} / \mathrm{II}$ & 26 & 10 & & 26 & 10 & & 18 & 18 & \\
\hline III/IV & 35 & 9 & & 34 & 10 & & 24 & 20 & \\
\hline
\end{tabular}

${ }^{a}$ Independent-sample t-test; ${ }^{b}$ Fisher's exact test; ${ }^{\mathrm{c}}$ continuity correction test; ${ }^{\mathrm{d}}$ Pearson's chi-squared test; ${ }^{\mathrm{e}}$ Statistically significant values (p<0.05); HCC, hepatocellular carcinoma; CYR61, cysteine-rich 61; CTGF, connective tissue growth factor; WISP, Wnt-induced secreted protein; NOV, nephroblastoma overexpressed protein.

While controlling for clinical details (age, gender, tumor size, AFP, HBsAg status, direct liver invasion, bile duct invasion, venous invasion, tumor microsatellite instability, cellular differentiation, pTNM stage and tumor relapse), Cox regression for multivariate survival analysis was performed to estimate the possible effects of the 5 genes on cancer prognosis. With the Enter method in Cox regression for survival, NOV was the most significant independent predictor for relative risk of death $(\mathrm{RR}=0.252, \mathrm{P}=0.002$ ) (Table V). Stepwise Cox regression for multivariate survival analysis using the method of Forward Stepwise Likelihood Ratio was used to evaluate the prognostic co-variates. The results showed that the best model for the HCC prognosis in the present study contained 2 covariates: NOV and CYR61 (Table V). The RR of NOV was 0.216, meaning that the survival probability for patients with positive NOV expression may be decreased to $21.6 \%$ of that of patients with negative NOV expression. While the RR of CYR61 was 2.77, which meant that the survival probability of patients whose tumors had enhanced CYR61 expression was 2.77-fold higher compared to those whose tumors showed decreased expression of CYR61.

\section{Discussion}

Previous studies have demonstrated that the $\mathrm{CCN}$ family of genes plays an important role in enhancing the tumorigenesis of many types of cancer. Inhibition of their expression in these tumors slows tumor growth. In contrast, several of these CCN proteins are expressed at lower levels in selected cancers, and by forcing their expression, tumor growth may be slowed or halted (10-12). In the present study, high expression levels of NOV and low expression levels of CYR61 and WISP1 appear to have profound effects on the behavior of $\mathrm{HCC}$, and may influence disease-free and overall survival.

NOV was first reported as an overexpressed gene in nephroblastomas induced by the myeloblastosis virus (17). Previous studies have suggested that NOV has a conflicting role in different types of cancers. For example, NOV had an inhibitory effect on cell growth in the C6 glioma cell line (18) and normal endothelial cells (19). Other investigators have shown that the amino-truncation of the NOV protein induced morphological transformation $(16,20)$ and oncogenic activation $(21,22)$. The NOV protein also promoted bone 
Table III. Correlations between overall survival and expression of NOV, WISP1, CYR61, CTGF and WISP2 in HCC patients.

\begin{tabular}{|c|c|c|c|c|c|}
\hline Factors & Alive $(n=41)$ & Deceased $(n=36)$ & Mean survival (days) & SE & P-value \\
\hline Age (years) & $49.83 \pm 12.1$ & $49.56 \pm 8.3$ & & & $0.880^{\mathrm{a}}$ \\
\hline Gender & & & & & $0.720^{\mathrm{b}}$ \\
\hline Male & 36 & 34 & $1,054.7$ & 80.4 & \\
\hline Female & 5 & 2 & 996.6 & 243.4 & \\
\hline Tumor size $(\mathrm{cm})$ & $7.1 \pm 4.6$ & $9.1 \pm 3.5$ & & & $0.024^{\mathrm{a}, \mathrm{c}}$ \\
\hline AFP & & & & & $0.663^{\mathrm{b}}$ \\
\hline Negative & 17 & 12 & $1,032.5$ & 109.6 & \\
\hline Positive & 24 & 24 & $1,046.7$ & 99.1 & \\
\hline HBsAg & & & & & $0.870^{\mathrm{b}}$ \\
\hline Negative & 7 & 5 & 989.7 & 165.2 & \\
\hline Positive & 34 & 31 & $1,060.4$ & 84.2 & \\
\hline Direct liver invasion & & & & & $0.033^{b, c}$ \\
\hline Negative & 18 & 10 & $1,295.1$ & 115.9 & \\
\hline Positive & 23 & 26 & 882.3 & 86.4 & \\
\hline \multicolumn{6}{|l|}{ Bile duct invasion } \\
\hline Negative & 37 & 25 & $1,097.4$ & 72.5 & $0.018^{\mathrm{b}, \mathrm{c}}$ \\
\hline Positive & 4 & 11 & 705.5 & 180.1 & \\
\hline Venous invasion & & & & & $<0.001^{\mathrm{b}, \mathrm{c}}$ \\
\hline Negative & 21 & 4 & $1,294.8$ & 67.2 & \\
\hline Positive & 30 & 32 & 862.5 & 93.0 & \\
\hline Tumor microsatellite instability & & & & & $0.001^{\mathrm{b}, \mathrm{c}}$ \\
\hline Negative & 31 & 16 & $1,266.3$ & 94.3 & \\
\hline Positive & 10 & 20 & 741.1 & 101.4 & \\
\hline Cellular differentiation & & & & & $0.155^{\mathrm{b}}$ \\
\hline $\mathrm{I} / \mathrm{II}$ & 24 & 16 & $1,111.1$ & 91.1 & \\
\hline III/IV & 17 & 20 & 928.4 & 113.0 & \\
\hline pTNM stage & & & & & $<0.001^{\mathrm{b}, \mathrm{c}}$ \\
\hline $\mathrm{I} / \mathrm{II}$ & 28 & 7 & $1,338.4$ & 78.5 & \\
\hline III/IV & 13 & 29 & 789.0 & 98.1 & \\
\hline NOV & & & & & $<0.001^{\mathrm{b}, \mathrm{c}}$ \\
\hline Negative & 29 & 6 & $1,329.4$ & 89.0 & \\
\hline Positive & 13 & 30 & 828.9 & 93.6 & \\
\hline WISP1 & & & & & $0.034^{\mathrm{b}, \mathrm{c}}$ \\
\hline Negative & 30 & 32 & 968.4 & 88.6 & \\
\hline Positive & 11 & 4 & $1,351.9$ & 103.4 & \\
\hline CYR61 & & & & & $0.030^{\mathrm{b}, \mathrm{c}}$ \\
\hline Low expression & 28 & 30 & 924.33 & 79.9 & \\
\hline High expression & 13 & 6 & $1,358.2$ & 144.8 & \\
\hline CTGF & & & & & $0.910^{\mathrm{b}}$ \\
\hline Negative & 32 & 26 & $1,011.2$ & 80.9 & \\
\hline Positive & 9 & 10 & 1079.1 & 156.1 & \\
\hline WISP2 & & & & & $0.151^{\mathrm{b}}$ \\
\hline Negative & 25 & 15 & $1,177.7$ & 109.8 & \\
\hline Positive & 16 & 21 & 897.3 & 92.1 & \\
\hline
\end{tabular}

${ }^{\mathrm{a}}$ Cox regression model test for continuous variable; ${ }^{\mathrm{l} l o g}$-rank test. ${ }^{\mathrm{c}} \mathrm{P}<0.05$ are set for statistically significant; HCC, hepatocellular carcinoma; CYR61, cysteine-rich 61; CTGF, connective tissue growth factor; NOV, nephroblastoma overexpressed protein; WISP, Wnt-induced protein. 
Table IV. Correlations among the expression levels of NOV, WISP1, CYR61, CTGF and WISP2 in the HCC sample.

\begin{tabular}{|c|c|c|c|c|c|c|c|c|}
\hline \multicolumn{2}{|c|}{ Genes } & \multicolumn{4}{|c|}{ Expression status of $\mathrm{CCN}$} & \multirow[b]{2}{*}{$\kappa$-value } & \multirow[b]{2}{*}{ SE } & \multirow[b]{2}{*}{$95 \% \mathrm{CI}$} \\
\hline A & $\mathrm{B}$ & $\mathrm{A}^{-} \mathrm{B}^{-}$ & $\mathrm{A}^{-} \mathrm{B}^{+}$ & $\mathrm{A}^{+} \mathrm{B}^{-}$ & $\mathrm{A}^{+} \mathrm{B}^{+}$ & & & \\
\hline NOV & WISP-1 & 28 & 8 & 37 & 7 & -0.059 & 0.083 & $-0.222,0.104$ \\
\hline NOV & CYR-61 & 32 & 4 & 39 & 5 & 0.002 & 0.065 & $-0.125,0.129$ \\
\hline NOV & CTGF & 29 & 7 & 31 & 13 & 0.095 & 0.09 & $-0.081,0.271$ \\
\hline NOV & WISP-2 & 23 & 13 & 19 & 25 & 0.204 & 0.108 & $-0.00768,0.416$ \\
\hline WISP-1 & CYR-61 & 60 & 5 & 11 & 4 & 0.224 & 0.135 & $-0.0406,0.489$ \\
\hline WISP-2 & CTGF & 52 & 13 & 8 & 7 & 0.236 & 0.123 & $-0.00508,0.477$ \\
\hline WISP-3 & WISP-2 & 37 & 28 & 5 & 10 & 0.148 & 0.09 & $-0.0284,0.324$ \\
\hline CYR-61 & CTGF & 55 & 16 & 5 & 4 & 0.143 & 0.116 & $-0.0844,0.370$ \\
\hline CYR-61 & WISP-2 & 40 & 31 & 2 & 7 & 0.142 & 0.074 & $-0.00304,0.287$ \\
\hline CTGF & WISP-2 & 37 & 23 & 5 & 15 & 0.282 & 0.096 & $0.0938,0.470$ \\
\hline
\end{tabular}

CI, confidence interval; HCC, hepatocellular carcinoma; CYR61, cysteine-rich 61; CTGF, connective tissue growth factor; NOV, nephroblastoma overexpressed protein; WISP, Wnt-induced protein.

Table V. Cox regression for multivariate overall survival analysis of NOV, WISP1, CYR61, CTGF, and WISP2 for the HCC patients.

A, Method $=$ Enter

\begin{tabular}{lccccr}
\hline Gene & N & Wald & RR & $95 \%$ CI & P-value \\
\hline NOV & 77 & 9.244 & 0.252 & $0.104-0.613$ & 0.002 \\
WISP1 & 77 & 3.506 & 2.84 & $0.952-8.468$ & 0.061 \\
CYR61 & 77 & 3.196 & 2.521 & $0.915-6.950$ & 0.074 \\
CTGF & 77 & 0.192 & 0.827 & $0.354-1.931$ & 0.661 \\
WISP2 & 77 & 1.486 & 0.637 & $0.308-1.316$ & 0.223 \\
\hline
\end{tabular}

B, Method $=$ Forward Stepwise Likelihood Ratio

\begin{tabular}{llllllll}
\hline Step & Gene & B & SE & Wald & RR & 95\% CI & P-value \\
\hline 1 & NOV & -1.534 & 0.449 & 11.68 & 0.216 & $0.089-0.52$ & 0.001 \\
2 & CYR61 & 1.01019 & 0.489 & 4.341 & 2.77 & $1.062-7.226$ & 0.037 \\
& NOV & -1.534 & 0.449 & 11.663 & 0.216 & $0.089-0.52$ & 0.001
\end{tabular}

CI, confidence interval; HCC, hepatocellular carcinoma; CYR61, cysteinerich 61; CTGF, connective tissue growth factor; NOV, nephroblastoma overexpressed protein; WISP, Wnt-induced protein.

metastasis in prostate cancer through the RANKL-dependent pathway (23). To our knowledge, this represents the first major analysis of NOV in tissue samples from HCC patients. In the present study, 44 of 80 (55\%) HCC samples overexpressed $\mathrm{NOV}$, and the expression levels were significantly upregulated in HCC samples compared to the matched non-cancerous tissues. Furthermore, the expression levels were significantly associated with venous invasion, cellular differentiation and pTNM stage in HCC patients, as well as disease-free and overall survival of HCC patients. These conclusions suggest that NOV may play an important role in the progression of HCC, which merits further investigation.

WISP1 was first identified as an upregulated gene in C57 MG mouse mammary epithelial cells transformed with Wnt-1 (8). Additionally, WISP1 has been suggested to either inhibit or enhance tumor development. For example, the expression of WISP1 was inversely correlated with the proliferation and metastatic growth of melanoma cells $(24,25)$. In contrast, human breast cancers overexpressed this protein (8). Overexpression of WISP1 promotes the growth of normal kidney fibroblasts in rats and induces tumor formation in nude mice (9). In the present study, we found that WISP1 was significantly downregulated in HCC samples. The expression level was inversely associated with tumor size, direct liver invasion, venous invasion, tumor microsatellite instability, pTNM stage, disease-free and overall survival.

The CYR61 protein was the first described member of the CCN family and has a rich cysteine motif. Previous studies have shown that CYR61 is overexpressed and tumorigenic in breast cancers (26), colon adenocarcinomas, and bladder papillomas (19). In contrast, forced expression of CYR61 in lung cancers slowed the growth of cancerous cells (27), Similarly, studies have shown that CYR61 is downregulated in HCC samples. Forced expression of CYR61 in HCC cell lines suppressed cell proliferation, whereas downregulation by siRNA increased cell proliferation, mainly though the DNA damage response and p53 pathways (28). In the present study, 71 of $80(88 \%)$ HCC samples had CYR61 expression levels significantly lower than that in the matched non-cancerous tissues. Furthermore, low expression levels of CYR61 were significantly associated with shorter disease-free and shorter overall survival of the HCC patients.

CTGF was discovered in the conditioned medium of human umbilical vein endothelial cells. Previous studies have shown that CTGF plays an oncogenic role in the development of human HCC (29). Downregulation of CTGF by inhibition of TGF- $\beta$ blocked the tumor-stroma crosstalk and tumor progression in HCC (30). Furthermore, CTGF was found to 
be involved in the development of liver fibrosis, mainly by hepatic stellate cells $(31,32)$, and indeed, fibrotic liver tissues express high levels of CTGF (33-36). Gressner et al reported that the serum CTGF-concentrations were higher in cirrhotic patients than in HCC patients with or without cirrhosis (37). The present study found that levels of CTGF were higher in non-cancerous tissues than that in matched HCC samples, most likely because many non-cancerous tissues were from patients with liver cirrhosis.

WISP2 was found to be upregulated in central nervous tissues in GM3-only mice (38) and is an oncogenic factor in human breast cancers $(39,40)$. In the present study, the expression levels of WISP2 in primary HCC showed no difference from levels in the paired non-cancerous tissues. Additionally, no significant relationship was found between the expression of WISP2 and the clinical features. These findings suggest that WISP2 may not be involved in the development of HCC.

In conclusion, our results revealed that the enhanced expression of NOV and decreased expression of WISP1 and CYR61 correlate statistically with the overall prognosis of HCC patients, as well as their pathological and clinical features. The data suggest that NOV appears to play an oncogenic role, while WISP1 and CYR61 may have suppressive roles in either the development or progression of HCC. These findings are the first steps in exploring the functional mechanisms by which the CCN protein family members participate in $\mathrm{HCC}$, which may include determining the signals that control the expression of these $\mathrm{CCN}$ proteins and promote the transformation and/or progression of HCC. Understanding these mechanisms will prove useful for the diagnosis, prognosis and therapy of HCC.

\section{Acknowledgements}

The present study was supported by grants from the Natural Science Foundation of China (81272956, 81372565, 81071788); grants from the ' 985 project' of Sun Yat-sen University; grants from the 'Team project' of Guangdong Provincial Department of Science and Technology (S2012030006287); Guangdong Provincial Department of Science and Technology Fund (2009B080701088); grants from Guangzhou Bureau of Science and Information Technology (2013J4500011); and by Key Laboratory of Guangdong Higher Education Institutes (KLB09001) and Guangzhou Bureau of Science and Information Technology [(2013)163 and 201400000004-2].

\section{References}

1. Parkin DM, Bray F, Ferlay J and Pisani P: Global cancer statistics, 2002. CA Cancer J Clin 55: 74-108, 2005.

2. Bosch FX, Ribes J, Cleries R and Diaz M: Epidemiology of hepatocellular carcinoma. Clin Liver Dis 9: 191-211, 2005.

3. Wong CM and Ng IO: Molecular pathogenesis of hepatocellular carcinoma. Liver Int 28: 160-174, 2008.

4. Guichard C, Amaddeo G, Imbeaud S, et al: Integrated analysis of somatic mutations and focal copy-number changes identifies key genes and pathways in hepatocellular carcinoma. Nat Genet 44 694-698, 2012.

5. Bork P: The modular architecture of a new family of growth regulators related to connective tissue growth factor. FEBS Lett 327: 125-130, 1993.

6. Brigstock DR: The CCN family: a new stimulus package. J Endocrinol 178: 169-175, 2003.

7. Perbal B: CCN proteins: multifunctional signalling regulators. Lancet 363: 62-64, 2004.
8. Pennica D, Swanson TA, Welsh JW, et al: WISP genes are members of the connective tissue growth factor family that are up-regulated in wnt-1-transformed cells and aberrantly expressed in human colon tumors. Proc Natl Acad Sci USA 95: $14717-14722,1998$.

9. Xu L, Corcoran RB, Welsh JW, Pennica D and Levine AJ: WISP-1 is a Wnt-1- and beta-catenin-responsive oncogene. Genes Dev 14: 585-595, 2000.

10. Lau LF and Lam SC: The CCN family of angiogenic regulators: the integrin connection. Exp Cell Res 248: 44-57, 1999.

11. Brigstock DR: The connective tissue growth factor/cysteine-rich 61/nephroblastoma overexpressed (CCN) family. Endocr Rev 20: 189-206, 1999.

12. Perbal B: The CCN family of genes: a brief history. Mol Pathol 54: 103-104, 2001.

13. Babic AM, Kireeva ML, Kolesnikova TV and Lau LF: CYR61, a product of a growth factor-inducible immediate early gene, promotes angiogenesis and tumor growth. Proc Natl Acad Sci USA 95: 6355-6360, 1998.

14. Igarashi A, Okochi H, Bradham DM and Grotendorst GR: Regulation of connective tissue growth factor gene expression in human skin fibroblasts and during wound repair. Mol Biol Cell 4: 637-645, 1993.

15. Duncan MR, Frazier KS and Abramson S, et al: Connective tissue growth factor mediates transforming growth factor beta-induced collagen synthesis: down-regulation by cAMP. FASEB J 13: 1774-1786, 1999.

16. Xie D, Nakachi K, Wang H, Elashoff R and Koeffler HP: Elevated levels of connective tissue growth factor, WISP-1, and CYR61 in primary breast cancers associated with more advanced features. Cancer Res 61: 8917-8923, 2001.

17. Joliot V, Martinerie C and Dambrine G, et al: Proviral rearrangements and overexpression of a new cellular gene (nov) in myeloblastosis-associated virus type 1-induced nephroblastomas. Mol Cell Biol 12: 10-21, 1992.

18. Gupta N, Wang H, McLeod TL, et al: Inhibition of glioma cell growth and tumorigenic potential by CCN3 (NOV). Mol Pathol 54: 293-299, 2001.

19. Babic AM, Kireeva ML, Kolesnikova TV and Lau LF: CYR61, a product of a growth factor-inducible immediate early gene, promotes angiogenesis and tumor growth. Proc Natl Acad Sci USA 95: 6355-6360, 1998.

20. Sakamoto K, Yamaguchi S, Ando R, et al: The nephroblastoma overexpressed gene (NOV/ccn3) protein associates with Notch1 extracellular domain and inhibits myoblast differentiation via Notch signaling pathway. J Biol Chem 277: 29399-29405, 2002.

21. Kocialkowski S, Yeger H, Kingdom J, Perbal B and Schofield PN: Expression of the human NOV gene in first trimester fetal tissues. Anat Embryol (Berl) 203: 417-427, 2001.

22. Lin CG, Leu SJ and Chen N, et al: CCN3 (NOV) is a novel angiogenic regulator of the CCN protein family. J Biol Chem 278: 24200-24208, 2003.

23. Chen PC, Cheng $\mathrm{HC}$ and Tang $\mathrm{CH}$ : $\mathrm{CCN} 3$ promotes prostate cancer bone metastasis by modulating the tumor-bone microenvironment through RANKL-dependent pathway. Carcinogenesis 34: 1669-1679, 2013.

24. Hashimoto Y, Shindo-Okada N, Tani M, Takeuchi K, Toma H and Yokota J: Identification of genes differentially expressed in association with metastatic potential of K-1735 murine melanoma by messenger RNA differential display. Cancer Res 56: 5266-5271, 1996.

25. Hashimoto Y, Shindo-Okada N and Tani M, et al: Expression of the Elm1 gene, a novel gene of the CCN (connective tissue growth factor, Cyr61/Cef10, and neuroblastoma overexpressed gene) family, suppresses In vivo tumor growth and metastasis of K-1735 murine melanoma cells. J Exp Med 187: 289-296, 1998.

26. Xie D, Miller CW, O'Kelly J, et al: Breast cancer. Cyr61 is overexpressed, estrogen-inducible, and associated with more advanced disease. J Biol Chem 276: 14187-14194, 2001.

27. Chen PP, Li WJ, Wang Y, et al: Expression of Cyr61, CTGF, and WISP-1 correlates with clinical features of lung cancer. PLoS One 2: e534, 2007.

28. Feng P, Wang B and Ren EC: Cyr61/CCN1 is a tumor suppressor in human hepatocellular carcinoma and involved in DNA damage response. Int J Biochem Cell Biol 40: 98-109, 2008.

29. Urtasun R, Latasa MU, Demartis MI, et al: Connective tissue growth factor autocriny in human hepatocellular carcinoma: oncogenic role and regulation by epidermal growth factor receptor/yes-associated protein-mediated activation. Hepatology 54: 2149-2158, 2011. 
30. Mazzocca A, Fransvea E, Dituri F, Lupo L, Antonaci S and Giannelli G: Down-regulation of connective tissue growth factor by inhibition of transforming growth factor beta blocks the tumor-stroma cross-talk and tumor progression in hepatocellular carcinoma. Hepatology 51: 523-534, 2010.

31. Hao C, Xie Y, Peng M, et al: Inhibition of connective tissue growth factor suppresses hepatic stellate cell activation in vitro and prevents liver fibrosis in vivo. Clin Exp Med 14: 141-150, 2014.

32. Huang G and Brigstock DR: Regulation of hepatic stellate cells by connective tissue growth factor. Front Biosci (Landmark Ed) 17: 2495-2507, 2012.

33. Wu G-Q, Liu N-F, Fan X-B, et al: The level of connective tissue growth factor in sera of patients with hepatitis B virus strongly correlates with stage of hepatic fibrosis. Viral Immunol 23: 71-78, 2010.

34. Wang K, Lin B, Brems JJ and Gamelli RL: Hepatic apoptosis can modulate liver fibrosis through TIMP1 pathway. Apoptosis 18 566-577, 2013

35. Bauer S, Eisinger K, Wiest R, et al: Connective tissue growth factor level is increased in patients with liver cirrhosis but is not associated with complications or extent of liver injury. Regul Pept 179: 10-14, 2012.
36. Sonnylal S, Shi-Wen X, Leoni P, et al: Selective expression of connective tissue growth factor in fibroblasts in vivo promotes systemic tissue fibrosis. Arthritis Rheum 62: 1523-1532, 2010.

37. Gressner OA, Fang M, Li H, Lu LG, Gressner AM and Gao CF: Connective tissue growth factor (CTGF/CCN2) in serum is an indicator of fibrogenic progression and malignant transformation in patients with chronic hepatitis B infection. Clin Chim Acta 421: 126-131, 2013.

38. Ohkawa Y, Ohmi Y, Tajima O, Yamauchi Y, Furukawa K and Furukawa K: Wisp2/CCN5 up-regulated in the central nervous system of GM3-only mice facilitates neurite formation in Neuro2a cells via integrin-Akt signaling. Biochem Biophys Res Commun 411: 483-489, 2011.

39. Davies SR, Watkins G, Mansel RE and Jiang WG: Differential expression and prognostic implications of the CCN family members WISP-1, WISP-2, and WISP-3 in human breast cancer. Ann Surg Oncol 14: 1909-1918, 2007.

40. Ferrand N, Stragier E, Redeuilh G and Sabbah M: Glucocorticoids induce CCN5/WISP-2 expression and attenuate invasion in oestrogen receptor-negative human breast cancer cells. Biochem J 447: 71-79, 2012. 